\title{
Assessing life cycle environmental impacts of inoculating soybeans in Argentina with Bradyrhizobium japonicum
}

\author{
Angelica Mendoza Beltran ${ }^{1}$ (1) . Claus Nordstrøm Scheel ${ }^{2} \cdot$ Nuala Fitton $^{3} \cdot$ Jannick Schmidt $^{4} \cdot$ Jesper Hedal Kløverpris ${ }^{2}$
}

Received: 8 July 2020 / Accepted: 18 May 2021 / Published online: 2 August 2021

(c) The Author(s) 2021

\begin{abstract}
Purpose To estimate life cycle impacts from introducing the yield-enhancing inoculant containing the nitrogen-fixing bacterium Bradyrhizobium japonicum and the signal molecule lipochitooligosaccharide (LCO) in Argentinian soybean production. The study focuses on soybeans grown in rotation with corn in the Buenos Aires province. We also provide the life cycle impact assessment for the inoculant production. The study represents a novel scope in terms of the studied crop, inoculant type, and location.

Methods Consequential LCA is used to assess the cradle-to-gate soybean production systems with and without inoculant use. Stepwise is used for quantification of 16 impacts at mid-point level. Also, the LCA-based guidance of Kløverpris et al. (2020) is followed, and we divide the change in impacts caused by the inoculant's use into four effects. The field effect accounts for changes in field emissions. The yield effect accounts for additional soybean production in the inoculant system that displaces soybean production elsewhere (system expansion). The upstream effect covers the inoculant production and the downstream effect covers post-harvest changes such as soybean transport and drying. Small plot field-trials data is applied in the biogeochemical model DayCent to estimate field emissions, among others.

Results and discussion The use of this inoculant reduces environmental impacts from soybean production in all studied impact categories. The main contributing factor is the yield effect, i.e., reduced impacts via avoided soybean production elsewhere including reduced pressure on land and thereby avoided impacts in the form of indirect land-use-change (iLUC). The field effect is the second-largest contributor to the overall impact reduction. Upstream and downstream effects only had minor influence on results. The yield and field effects are closely tied to the yield change from the inoculant use, which was not fully captured in the DayCent modeling. Thereby, a potential underestimation of the environmental benefits of roughly $10 \%$ can be expected, corresponding to the difference of empiric yield data and the modeled yield data in DayCent.

Conclusion and recommendations The use of this inoculant shows environmental benefits and no trade-offs for the 16 impacts assessed. Results depend primarily on avoided soybean production (the yield effect) which entails iLUC impacts in Brazil and USA, and to a lesser degree on field emissions modelled with DayCent. Better data and parametrization of DayCent, to better capture the change in yields and estimate field emissions, economic modelling for the system expansion assumptions, and accounting for uncertainty in iLUC modelling could improve the assessment.
\end{abstract}

Keywords Environmental impact $\cdot \mathrm{N}$-fixation $\cdot$ Inoculant $\cdot$ Soybean $\cdot$ Agricultural practices

Communicated by Greg Thoma.

Jesper Hedal Kløverpris

jklp@novozymes.com

Angelica Mendoza Beltran

angelica.mendoza@uab.cat

1 Institute of Environmental Science and Technology (ICTA), Universitat Autonoma de Barcelona (UAB), Barcelona, Spain
2 Novozymes A/S, Biologiens vej 2, 2800 Kgs. Lyngby, Denmark

3 Institute of Biological and Environmental Sciences, University of Aberdeen, Cruickshank Building, 23 St. Machar Drive, Aberdeen AB24 3UU, UK

4 Department of Planning, Aalborg University, Rendsburggade 14, room 1.431, 9000 Aalborg, Denmark 


\section{Introduction}

In the past, the main goals of agricultural optimization were solely related to productivity improvement. For instance, yield enhancements and economic optimization were prioritized without further considering potential environmental trade-offs that some practices could give rise to (Foley et al. 2011; van Noordwijk and Brussaard 2014). Today, the drive for productivity is increasingly combined with a need for agricultural sustainability (Leggett et al. 2017). This implies that an important additional aim is to minimize environmental impacts of food consumed. Some alternatives to achieve this are for instance, reducing land use and chemical use, or ensuring optimal nutrient and carbon balances in agricultural soils (Horrigan et al. 2002). Sustainable agricultural practices have already been widely documented (Tilman et al. 2001; Godfray et al. 2010; Rockström et al. 2017) and inoculants-also known as biofertilizersis a technology combining agricultural optimization with a sustainability focus (Santos et al. 2019). Agricultural inoculants have been known for more than a century and are broadly used while still holding further potential for widespread use (Santos et al. 2019). Soybean inoculation is largest in South American countries while in the USA only about $15 \%$ of the area with soybean cultivation has been inoculated (Santos et al. 2019).

Generally, inoculants contain microorganisms that target specific processes in growing plants or the surrounding soil to enhance the health and growth of plants (Nadeem et al. 2013) and therefore may change productivity. For instance, the microbial phosphate inoculant $P$. bilaiae aids the uptake of soil nutrients in corn plants causing higher yields (Leggett et al. 2015) and overall environmental benefits such as reduction of global warming and nutrient enrichment impacts (Kløverpris et al. 2020). Likewise, there is a specific type of agricultural inoculants within the nitrogen $(\mathrm{N})$ fixing category that focuses on symbiotic $\mathrm{N}$-fixation. Availability of $\mathrm{N}$ is often the limiting soil nutrient factor for plant growth (Andrews et al. 2003), and thus, the symbiotic relation between the plant and the microorganism that enhances $\mathrm{N}$-fixation has potential to increase crop yields. That is the case for the symbiosis between soybean and the bacterial inoculant made with Bradyrhizobium (Keyser and Li 1992). Several reviews have shown the positive effects of a range of $\mathrm{N}$-fixing bacteria, among others, on plant nutrient uptake and $\mathrm{N}$ availability (Andrews et al. 2003; Adesemoye and Kloepper 2009; Di Benedetto et al. 2017; Backer et al. 2018).

In addition to the productivity debate (Adesemoye and Kloepper 2009; Backer et al. 2018), a broader environmental assessment of the use of inoculants would be more relevant for agricultural sustainability assessments. Recent research has focused on identifying possible ways in which inoculants may help in the reduction of environmental impacts. For instance, Nadeem et al. (2013) reviewed the potential of bacterial inoculants in future sustainable agriculture and suggests that inoculants could reduce the impact of biotic and abiotic stress factors such as pathogen attach and extreme temperature, and thereby increase, for instance, climate resilience of crops. Alori and Babalola (2018) identified the additional potential of inoculants use to reduce agro-chemicals such as pesticides and chemical fertilizers, similar to the study by Alves et al. (2003) who found that $\mathrm{N}$ fertilizer could be completely avoided for soybean produced in Brazil when properly inoculated with Bradyrhizobium. The knowledge on the mechanisms of action of the microbial inoculants plays a vital role in their use for sustainable agriculture. For instance, understanding their relationship with nutrient flows, yields and agricultural inputs, is vital information to understand their environmental impacts. Yet, to our knowledge, only one study quantified the environmental effects of introducing inoculants in agricultural practices.

Kløverpris et al. (2020) use life cycle assessment (LCA), as per ISO 14040 (ISO 2006), as a basis for articulating specific methodological guidance (detailed in Sect. 2.2) with respect to assessing the environmental consequences of alternative agricultural practices. With this methodology, they assess the effects of introducing a microbial phosphate inoculant as a yield-enhancer in the production of corn in the USA. Results show that the environmental consequences of introducing a microbial phosphate inoculant to corn are significant environmental benefits with no trade-offs, in particular reduction of climate change, eutrophication and land use change impacts. These benefits come from reduction in direct emissions from the cropland and from reduced use of land and other agricultural inputs elsewhere when more crop can be grown on the same field. Besides this application of the methodological guidance of Kløverpris et al. (2020), no other crops, inoculant types and locations have been studied with it or with LCA more broadly.

In the present study, we apply the LCA-based methodological framework described by Kløverpris et al. (2020) to a new inoculant, crop rotation, and region. We study soybean production in a corn-soybean rotation, with and without the use of a novel $\mathrm{N}$-fixing inoculant in the Buenos Aires region of Argentina. The inoculant contains a naturally occurring, root-nodulating, microsymbiotic $\mathrm{N}$-fixing bacterium called Bradyrhizobium japonicum and a signal molecule called lipochitooligosaccharide (LCO). The inoculant is manufactured by Novozymes and is nowadays marketed under the name Nitragin Optimize ${ }^{\circledR}$ II (from here on referred to as the inoculant) in Argentina. The signal molecule (LCO) increases the consistency and effectiveness of 
the rhizobium-soybean symbiosis. This molecule initiates nodulation, stimulates the root system, and enhances nodule development leading to enhanced $\mathrm{N}$-fixation (Leggett et al. 2017). The inoculant action on soybean cultivation follows several steps. Newly emerged soybean plants rely on their cotyledon leaves as a source of N. Once that supply is exhausted, the $\mathrm{N}$-deficient plant exudes flavonoid signal molecules. The rhizobia bacteria in the soil sense the flavonoids and release their own unique signal molecule, the LCO molecule (nod factor). This signal molecule initiates a process of root cell elongation and cell division creating infection sites for the symbiotic rhizobia bacteria within the soybean roots. This inoculant replaces the need for the plants to wait until the nodulation cycle is complete by bypassing the need to release the flavonoids from the plants and/or the release of LCO. The LCO molecule is present on the seed as well as the rhizobia inoculant, starting the growth process and rhizobia nodulation at emergence. Nodulation timing, root length, and volume can increase greatly. This changes $\mathrm{N}$ and carbon (C) nutrient cycles, crop yields (Leggett et al. 2017), and general plant growth, thereby also affecting the amount of plant residues.

This study will not only provide an assessment of the environmental impacts of the use of LCO-fortified Bradyrhizobium japonicum in soybean production in Buenos Aires, Argentina but also the life cycle impact assessment for the inoculant production which could be of use in other LCA studies.

In the following sections, we first explain how we implement and capture the mode of action of the inoculant within the goal, scope and life cycle inventory of the LCA. We then present the results and discuss the limitations and uncertainties around the LCA. Finally, we conclude and recommend further improvements and research.

\section{Methods}

\subsection{Goal and scope}

The goal of this study is to quantify environmental consequences of introducing an inoculant containing Bradyrhizobium japonicum and LCO in conventional soybean production from cradle-to-gate using a consequential LCA. The functional unit is one metric ton $(\mathrm{Mg})$ of dried soybeans at farm, ready for the market (13\% moisture at harvest and $11 \%$ moisture after drying). The soybean is cultivated in the province of Buenos Aires, Argentina (referred to as AR) in a corn-soybean rotation. The geographic scope is at the province level, as the corresponding largest multi-annual dataset for yields ( $n=58)$ is available at this level (Leggett et al. 2017). Field data collection took place between 2009 and 2013, and the temporal scope of the study is within the short-term future. Figure 1 shows the data flows from field trial data to life cycle inventory data. The full inventory and its calculation are described in coming sections.

The method used for life cycle impact assessment (LCIA) is Stepwise 2006, version 1.7. The method is described and documented in Annex II of Weidema et al. (2008) and in Weidema (2009), and updates for nature occupation in Schmidt and Saxcé (2016). The characterization module of Stepwise is based on a combination of the Impact 2002+ method (Jolliet et al. 2003) and the EDIP 2003 method (Hauschild and Potting 2005). For the detailed description of the impact categories and methods in Stepwise, see the electronic supplementary material (ESM), Sect. 1.2. Results are presented at mid-point level of impact, i.e., without normalization and weighting.

\subsection{Four environmental effects from the use of Bradyrhizobium japonicum}

Two systems are compared as this study focuses on the changes in environmental impacts from introducing the inoculant. In the reference system (Ref), soybean is grown conventionally in rotation with corn. Here, standard agricultural inputs are applied to the field and then harvested and dried to get an output of corn in year 1 and soybean in year 2 . The second system is the inoculant system which considers soybean grown with Bradyrhizobium japonicum (referred to as $B . j-L C O$ ) in year 2 following conventional corn production in year 1. It is assumed that the corn output in uneven years (year $1,3,5, \ldots, 99$ ) is unaffected by the introduction of the inoculant for the biogeochemical modelling period of 100 years, as will be detailed further.

Following the approach by Kløverpris et al. (2020), the two systems are divided into four categories, i.e., upstream, field, yield, and downstream and the difference in impact between the two systems within each category is referred to as an "effect." The upstream effect includes the production of the inoculant in the inoculant system. The field effect includes a change in direct emissions from the field in the inoculant system in comparison with the reference system. The yield effect considers the higher output of soybean in the inoculant system per unit of area compared to the reference system. To ensure that the two systems provide the same output, i.e., that the two systems are "equivalent" and therefore comparable, the inoculant system is expanded to include displacement of marginal soybean production elsewhere. Finally, the downstream effect accounts for changes in drying and transport from field to farm in the inoculant system compared to the reference. See the ESM, Sect. 1.1, for details on the equations to calculate each effect.

Figure 2 shows the reference and the inoculant systems. Figure 2 also shows the cultivated area in both systems (A), the output of soybeans from area $\mathrm{A}$ in the reference system 
$(\mathrm{Q})$, the increase in soybean output from area $\mathrm{A}$ when the inoculant is used $(\Delta \mathrm{Q})$ and the area of soybean production displaced when the inoculant is used (B). These are all important parameters to determine the individual effects (ESM, Sect. 1.1).

\subsection{Inventory}

The inventory data and assumptions for the effects' modelling are described here. Details for the area A in the reference system and the inoculant system are available in Table 1.

\subsubsection{Upstream effect: the inoculant production}

The inoculant production takes place in a fermentation facility and has three main stages: the laboratory, the fermentation, and the post-fermentation stage. In general, all inventory flows are estimated based on the inoculant's production of the total volume of liquid processed at the fermentation facility in 2017. For the materials, energy, transport, emissions, waste streams, and capital goods and services that are included in this inventory, see the ESM, Sect. 2.1.

Finally, the amount of inoculant used in the inoculant system is $0.15 \mathrm{~kg}$ per ha, as estimated based on the recommended dose for all Nitragin Optimize ${ }^{\circledR}$ II products for South America and the assumed standard seeding rate (USDA 2019).

\subsubsection{Field effect}

Soybean cultivation and biogeochemical modelling with DayCent The DayCent model was used to simulate the use of the inoculant in the soybean production (Del Grosso et al. 2001, 2006; Parton et al. 2001). Initially, DayCent simulates the corn-soybean rotation for the reference scenario. For this, input parameters include temperature, precipitation, soil texture, plant growth, and management events such as fertilization and harvests. Data for these parameters were obtained from a regional calibration of data for soybean after corn production, combining typical productivity and management practices sourced from agronomic experts from Novozymes, with soil (most dominant soil type) and climate (daily climate data averaged across the region) parameters sourced from the Harmonized World Soil Database (HWSD) and National Aeronautics and Space Administration (NASA) databases, respectively.

Two additional assumptions were made to model the inoculant mode of action system. First, the average percentage change in soybean yield achieved by the inoculant system and simulated in DayCent is based on data obtained from the field data for Buenos Aires (Sect. 2.3.3). Second, the effect of the inoculant in plant growth and $\mathrm{N}$ uptake by the plant was simulated by gradually increasing the parameter in DayCent that defines the maximum amount of $\mathrm{N}$ fixed per gram of $\mathrm{C}$ fixed via net primary production (NPP), if there is insufficient $\mathrm{N}$ within the soil. This parameter is called the SNFXMX parameter and it was gradually increased until the average percentage change in soybean yield with inoculant use from the field was achieved in the simulations. Modification of this parameter is used as a simple yet representative proxy to characterize the inoculant's mode of action, particularly capturing the effect the inoculant has on plant growth and on $\mathrm{N}$ uptake within the model. The baseline rate of $\mathrm{N}$-fixation without the use of the inoculant had a value of $0.003 \mathrm{~g}$ $\mathrm{N} / \mathrm{g}$ C NPP i.e. this is the SNFXMX value for the reference system. Simulations for both systems run for a 100-year period. More details on DayCent modelling are provided in the ESM, Sect. 2.2.1. The key DayCent outputs were the nutrient balances shown in the ESM, Sect. 2.2.2. These are the base for the inventory of the cultivation process emissions as explain below.

Cultivation emissions based on DayCent simulations DayCentmodelled outputs include soil organic carbon (SOC) content, $\mathrm{CH}_{4}$ emissions from aerobic and anaerobic reactions, $\mathrm{N}$ in plant grain, as well as $\mathrm{N}$-related emissions to air, i.e., $\mathrm{N}_{2} \mathrm{O}$ (direct), $\mathrm{NH}_{3}, \mathrm{NO}, \mathrm{N}_{2}$, and $\mathrm{NO}_{3}{ }^{-}$emissions to water for the reference and inoculant systems. SOC changes between systems were used to estimate $\mathrm{CO}_{2}$ emissions (see below). Change in $\mathrm{N}_{2} \mathrm{O}$ emissions are observed because the inoculant can promote root growth and plant productivity. Over a long period of time, the increase in plant productivity returns higher $\mathrm{C}$ inputs into the soil, resulting in a higher soil $\mathrm{C}$ level in the inoculant system compared to the reference system. This in turn results in a slight increase in the corn yields $(\sim 0.4 \%)$ over the 100-year period, too. Soil $\mathrm{C}$ and its retention within the soil is key to soil health and its relationship with crop yields is well established (Oldfield et al. 2019). Therefore, the modelled change in corn yields may also be expected. However, the increase in corn yield has conservatively been omitted in the LCA as it is assumed that corn production inputs and outputs (including emissions) remain the same in both systems. This is because, while corn yields increase, the level of increase is so small $(\sim 0.4 \%)$, it cannot be safely assumed that fertilizer application or any other management activates around corn would change due to the presence of the inoculant. Table 1 shows the emissions based on DayCent simulations as used in the inventory for soybean, as well as the simulated emissions for corn, for indication. The ESM, Sect. 2.2.2, shows the uncertainty parameters of the DayCent modelled emissions.

SOC-related emissions The SOC emissions are calculated with a time-independent approach elaborated by Schmidt 
Table 1 Inventory of soybean production in a corn-soybean rotation, with (B.j-LCO) and without (Ref) the use of inoculant. All flows normalized to 1 ha

\begin{tabular}{|c|c|c|c|c|c|c|}
\hline \multirow{2}{*}{$\begin{array}{l}\text { Flow } \\
\text { Output }\end{array}$} & \multirow[t]{2}{*}{ Unit } & \multicolumn{2}{|r|}{ Ref } & \multicolumn{2}{|r|}{ B.j-LCO } & \multirow[t]{2}{*}{ Data source (section) } \\
\hline & & Value & $\begin{array}{l}\sigma_{\mathrm{g}}^{2} \text { (pedigree } \\
\text { scores)*** }\end{array}$ & Value & $\sigma_{\mathrm{g}}^{2}$ (pedigree scores) $* * *$ & \\
\hline Soybean yield (DayCent) & $\mathrm{Mg}$ & 2.626 & 2.29 & $2.747^{*}$ & 2.13 & $\begin{array}{l}\text { Selected data from Leggett } \\
\text { et al. (2017), Sect. 2.3.3 }\end{array}$ \\
\hline \multicolumn{7}{|l|}{ Inputs } \\
\hline Pesticide application & ha & 4.30 & - & 4.30 & - & $\begin{array}{l}\text { Leggett et al. (2017), } \\
\text { Sect. 2.3.2 }\end{array}$ \\
\hline Combine harvesting & ha & 0.30 & - & 0.30 & - & Ecoinvent v3.4, Sect. 2.3.2 \\
\hline Tillage & ha & 0 & - & 0 & - & $\begin{array}{l}\text { Leggett et al. (2017), } \\
\text { Sect. 2.3.2 }\end{array}$ \\
\hline Sowing & ha & 1.00 & - & 1.00 & - & Ecoinvent v3.4, Sect. 2.3.2 \\
\hline Fertilizing & ha & 1.00 & - & 1.00 & - & $\begin{array}{l}\text { Leggett et al. (2017), } \\
\text { Sect. 2.3.2 }\end{array}$ \\
\hline Phosphate fertilizer, as $\mathrm{P}_{2} \mathrm{O}_{5}$ & $\mathrm{~kg}$ & 11.45 & - & 11.45 & - & $\begin{array}{l}\text { Selected data from Leggett } \\
\text { et al. (2017), Sect. 2.3.2 }\end{array}$ \\
\hline $\begin{array}{l}\text { Packaging, for fertilizers and } \\
\text { pesticides }\end{array}$ & $\mathrm{kg}$ & 12.37 & - & 12.37 & - & Calculated proxy \\
\hline Pyrethroid-compound & $\mathrm{kg}$ & 0.06 & - & 0.06 & - & Ecoinvent v3.4, Sect. 2.3.2 \\
\hline $\begin{array}{l}\text { Organophosphorus-compound, } \\
\text { unspecified }\end{array}$ & $\mathrm{kg}$ & 0.53 & - & 0.53 & - & Ecoinvent v3.4, Sect. 2.3.2 \\
\hline Phenoxy-compound & $\mathrm{kg}$ & 0.30 & - & 0.30 & - & Ecoinvent v3.4, Sect. 2.3.2 \\
\hline Glyphosate & $\mathrm{kg}$ & 0.003 & - & 0.003 & - & Ecoinvent v3.4, Sect. 2.3.2 \\
\hline Triazine-compound, unspecified & $\mathrm{kg}$ & 0.02 & - & 0.02 & - & Ecoinvent v3.4, Sect. 2.3.2 \\
\hline Seeds & $\mathrm{kg}$ & 65.6 & - & 65.6 & - & (USDA 2019), Sect. 2.3.2 \\
\hline Water & 1 & 0 & - & 0 & - & $\begin{array}{l}\text { Leggett et al. (2017), } \\
\text { Sect. 2.3.2 }\end{array}$ \\
\hline Transport field to farm & $\mathrm{tkm}$ & 41.55 & $3.18(4,4,4,4,4,2.0)$ & 43.46 & $3.18(4,4,4,4,4,2.0)$ & Calculated proxy, Sect. 2.3.4 \\
\hline Drying of soybean & 1 & 68.22 & $2.46(4,4,4,4,4,1.05)$ & 71.36 & $2.46(4,4,4,4,4,1.05)$ & Calculated proxy, Sect. 2.3.4 \\
\hline Inoculant & $\mathrm{kg}$ & 0 & $1.55(2,2,1,2,1,1.05)$ & 0.150 & $1.55(2,2,1,2,1,1.05)$ & $\begin{array}{l}\text { Recommended dose, } \\
\text { Sect. 2.3.1 }\end{array}$ \\
\hline Land occupation & ha year ${ }^{-1}$ & 1 & - & 1 & - & Area A, Sect. 2.3.2 \\
\hline Market for arable land $\{$ GLO $\}$ & ha year & 1 & - & 1 & - & iLUC, Sect. 2.3.2 \\
\hline \multicolumn{7}{|l|}{ Avoided production } \\
\hline Soybean $\{$ GLO $\} \mid$ market for & $\mathrm{kg}$ & 0 & - & -121 & 28.9 & $\begin{array}{l}\text { Avoided production, } \\
\text { Sect. 2.3.3 }\end{array}$ \\
\hline \multicolumn{7}{|l|}{ Emissions for soybean } \\
\hline $\mathrm{NH}_{3}-\mathrm{N}$ emissions to air & $\operatorname{kg~N}$ & 3.66 & 3.47 & 3.67 & 3.45 & DayCent, Sect. 2.3.2 \\
\hline NO-N emissions to air & $\mathrm{kg} \mathrm{N}$ & 0.76 & 4.83 & 0.77 & 4.79 & DayCent, Sect. 2.3.2 \\
\hline $\mathrm{N}_{2} \mathrm{O}-\mathrm{N}$ emissions (direct) to air & $\operatorname{kg~N}$ & 0.576 & 4.75 & 0.582 & 4.68 & DayCent, Sect. 2.3.2 \\
\hline $\mathrm{N}_{2}-\mathrm{N}$ emissions to air & $\operatorname{kg~N}$ & 0.25 & 8.01 & 0.16 & 15.52 & DayCent, Sect. 2.3.2 \\
\hline $\mathrm{CH}_{4}$ emissions to air & $\mathrm{kg} \mathrm{CH}_{4}$ & 2.17 & 1.12 & 2.16 & 1.12 & DayCent, Sect. 2.3.2 \\
\hline $\begin{array}{l}\mathrm{N}_{2} \mathrm{O}-\mathrm{N} \text { emissions (indirect) } \\
\text { to air }\end{array}$ & $\operatorname{kg~N}$ & 0.1067 & - & 0.1072 & - & IPCC, Sect. 2.3.2 \\
\hline $\mathrm{NO}_{3}^{-}-\mathrm{N}$ emissions to water & $\operatorname{kg~N}$ & 8.33 & 10.28 & 8.37 & 10.13 & DayCent, Sect. 2.3.2 \\
\hline Phosphate emission to water & $\mathrm{kg} \mathrm{P}$ & 0 & - & 0 & - & $\begin{array}{l}\text { Dalgaard et al. (2006), } \\
\text { Sect. 2.3.2 }\end{array}$ \\
\hline $\begin{array}{l}\mathrm{SOC} \mathrm{CO}_{2} \text { emissions to air } \\
\text { Emissions from corn*** }\end{array}$ & $\mathrm{kg} \mathrm{CO}_{2}$ & 0 & - & -18.3 & $1.37 * * *$ & DayCent, Sect. 2.3.2 \\
\hline $\mathrm{NH}_{3}-\mathrm{N}$ emissions to air & $\operatorname{kg~N}$ & 5.42 & - & 5.56 & - & DayCent, Sect. 2.3.2 \\
\hline $\mathrm{NO}-\mathrm{N}$ emissions to air & $\operatorname{kg~N}$ & 1.41 & - & 1.41 & - & DayCent, Sect. 2.3.2 \\
\hline $\mathrm{N}_{2} \mathrm{O}-\mathrm{N}$ emissions (direct) to air & $\mathrm{kg} \mathrm{N}$ & 0.93 & - & 0.94 & - & DayCent, Sect. 2.3.2 \\
\hline $\mathrm{N}_{2}-\mathrm{N}$ emissions to air & $\operatorname{kg~N}$ & 0.17 & - & 0.28 & - & DayCent, Sect. 2.3.2 \\
\hline
\end{tabular}


Table 1 (continued)

\begin{tabular}{|c|c|c|c|c|c|c|}
\hline \multirow{2}{*}{$\frac{\text { Flow }}{\text { Output }}$} & \multirow[t]{2}{*}{ Unit } & \multicolumn{2}{|r|}{ Ref } & \multicolumn{2}{|r|}{$B . j-L C O$} & \multirow[t]{2}{*}{ Data source (section) } \\
\hline & & Value & $\begin{array}{l}\sigma_{\mathrm{g}}{ }^{2}(\text { pedigree } \\
\text { scores)*** }\end{array}$ & Value & $\sigma_{\mathrm{g}}^{2}$ (pedigree scores) $* * *$ & \\
\hline$\overline{\mathrm{CH}_{4} \text { emissions to air }}$ & $\mathrm{kg} \mathrm{CH}$ & 2.08 & - & 2.08 & - & DayCent, Sect. 2.3.2 \\
\hline $\begin{array}{l}\mathrm{N}_{2} \mathrm{O}-\mathrm{N} \text { emissions (indirect) } \\
\text { to air }\end{array}$ & $\mathrm{kg} \mathrm{N}$ & 0.163 & - & 0.165 & - & IPCC, Sect. 2.3.2 \\
\hline $\mathrm{NO}_{3}{ }^{-}-\mathrm{N}$ emissions to water & $\mathrm{kg} \mathrm{N}$ & 12.63 & - & 12.74 & - & DayCent, Sect. 2.3.2 \\
\hline Phosphate emission to water & $\mathrm{kg} \mathrm{P}$ & n.a & - & n.a & - & $\begin{array}{l}\text { Dalgaard et al. (2006), } \\
\text { Sect. 2.3.2 }\end{array}$ \\
\hline
\end{tabular}

${ }^{*}$ To avoid double counting, the yield entered in the SimaPro software for the inventories is $2.626 \mathrm{Mg} / \mathrm{ha} *$ year. The table shows the actual yields to display the change between systems

** DayCent modelled emissions for corn are shown for indication here. It was assumed no inputs or outputs of corn production changed between systems

${ }^{* * * *}$ Uncertainty information for selected flows of the reference and inoculant systems in AR. $\sigma_{\mathrm{g}}^{2}$ is included in SimaPro together with lognormal distribution for all flows to characterize their uncertainty, except for $\mathrm{SOC}$ for which the assumed distribution for $\mathrm{CO}_{2}$ emissions is normal in order to account for the negative emissions

and Brandão (2013), building on the time-independent, decay-function-based $\mathrm{CO}_{2}$ characterization factors described by Petersen et al. (2013). Kløverpris et al. (2020) recommends the use of the time-independent approach which looks at the change in radiative forcing related to a single event, in this case, one year of soybean production with inoculant use. The inoculant application impacts the trend of SOC over the subsequent time period. This trend can be compared to the trend in the reference scenario (without inoculant) and, in this way, changes can be estimated. The estimated change in SOC emission are -18.3 in $\mathrm{kg} \mathrm{CO}_{2} \mathrm{ha}^{-1}$ year $^{-1}$ for the 100-year modelled period (ESM, Sect. 2.2.3, and Appendix II). An additional annualized approach to calculate SOC emissions (for 20 and 50 years) is described in the ESM, Sect. 2.2.3, and it is used in the sensitivity scenarios (see ESM, Sect. 4).

Residues The LCA follows DayCent modelling of biomass from residues (Abodeely et al. 2012). At harvest, DayCent separates the entire above and belowground biomass into grain and "other biomass." The other biomass is divided into a fraction returned to the field, i.e., left behind (residues) and adding nutrients to either soy or corn (thus accounted for in the nutrient balances), and the remaining is removed from the field. The fraction removed has been set to $70 \%$ of the total residues following previous DayCent runs from Fitton et al. (2014, 2017). The difference of removed residues between inoculant and reference systems in Mg dry matter ha ${ }^{-1} \mathrm{yr}^{-1}$ for corn is 0.02 and 0.16 for soybean (ESM, Sect. 2.2.4). No inventory assumption was made on the treatment of these removed residues because it is not clear what happens to them after being removed and the range of treatment options is large, as discussed in the ESM. This is a cutoff of the system. More data collection from the field practices could improve the assessment.

Other field emissions Other field emissions included in the inventory were indirect $\mathrm{N}_{2} \mathrm{O}$ emissions to air and phosphate emissions to water (Table 1). Indirect $\mathrm{N}_{2} \mathrm{O}$ emissions were estimated using the IPCC 2006 Guidelines for National Greenhouse Gas Inventories Tier 1 (De Klein et al. 2006) and N-related parameters calculated with DayCent, i.e., N-volatilization, $\mathrm{N}$-redeposition, N-leaching, ammonia emissions, NOx emissions, and nitrate emission to water. Calculation details are shown in the ESM, Sect. 2.2.5.

Phosphate emissions are calculated based on Dalgaard et al. (2006) as a fraction of $2.9 \%$ of the surplus of P, estimated as the difference between phosphate fertilizer input and phosphorus removal in the crop. Similar to DayCent emissions, these emissions are only estimated for soybean production as corn cultivation is assumed to remain the same between systems. More details of this calculation are shown in the ESM, Sect. 2.2.5.

Other inputs to soybean cultivation Other inputs to soybean cultivation considered are as follows: seeds, fertilizers and packaging, pesticides and packaging, energy use for crop management (plant protection applications, harvesting, tillage, ploughing, sowing, and fertilizing), and water use (Table 1). Assumptions and background processes used for each input are described in the ESM, Sect. 2.2.6. These inputs remain the same on area A, for the reference and inoculant systems, and were added, for completeness. Land-usechange (LUC) was also added for completeness and remains equal between systems. It is accounted in the form of direct 
and indirect land use change (dLUC and iLUC) and has the same magnitudes for the reference and inoculant systems i.e. one ha $\mathrm{yr}^{-1}$ of occupied arable land for dLUC and one ha yr for iLUC, linked to the global marginal market for land (ESM, Sect. 2.2.7, and Schmidt et al. 2015) and (Table 1). For more details on LUC accounting and modelling, see the ESM, Sect. 2.2.6.

\subsubsection{Yield effect}

Yield modelling Field trial data (Leggett et al. 2017) was collected for nine provinces in Argentina (ESM, Sect. 2.3.1). Yields had a relative increment of $6.4 \%$ due to the inoculant use. These data were refined to a smaller dataset via a plot analysis (ESM, Sect. 2.3.1), resulting in a dataset that contains data only from Buenos Aires, Argentina, with a relative increment of yields of 5.1\% $(n=58)$. The final relative yield increment used in the LCA was determined with this dataset and with DayCent simulations as explained in Sect. 2.3.2. The resulting modelled yield increase was $4.6 \%$ in Buenos Aires. All yield-related values are shown in Table 2. The difference between change in modelled yields $(4.6 \%)$ and change in yields from the plot analysis for Buenos Aires $(5.1 \%)$ is about a $10 \%$, yet it is the closest long-term match achieved by means of the simulations. The impossibility to replicate the plot analysis yields in DayCent is rooted in two reasons. First, the annual modelled yield, and yield response to the presence of the inoculant is not fixed and varies in relation to the climate, as a consequence interannual variation in soybean yield is greater than the increase in yield due to the inoculant use. Secondly, the change in yield, due to the presence of the inoculant, was smaller in years with projected lower yields.

The modelled relative change in yields leads to a total change in production between the systems with and without inoculant of $0.121 \mathrm{mg} \mathrm{DM} \mathrm{ha}^{-1}$ year $^{-1}$ (Table 2). This is the value used for the system expansion as the avoided soybean production in the global marginal market of soybean due to the inoculant use (Table 1). We use the DayCent modelled yields to keep consistency with the modelled emissions within the LCI, despite them being lower than those from the plot analysis. The use of lower modelled yields leads to a conservative assessment of the benefits from the inoculant use.

Global marginal market of soybean According to the methodology to identify marginal suppliers in LCA described in Weidema et al. (2009) and Weidema (2003), the marginal producers (on a country level) are the first to react to changes in the market, e.g. in demand. Similarly, they would be the first producers to pause production increases if a new technology (e.g., a yield-enhancing inoculant) increased supply elsewhere. Hence, it is assumed that the producers, that would first react to a change in demand, are located in the countries with the recently largest increase in production (i.e., an assumed reaction to increasing demands). Based on a linear regression of FAOSTAT data from 2012 to 2016 (FAO 2018), the marginal suppliers of soybean in the global market were assessed to be located in USA and Brazil, where the largest increases were observed. Together, the two countries represent about $60 \%$ of the global production of soybeans. The distribution of $52 \%$ soybeans from USA and $48 \%$ soybeans from Brazil in the marginal market corresponds to a scaled share of global production but only accounting for these countries (ESM, Sect. 2.3.2).

The life cycle inventory for soybean production in the USA and Brazil for this market is based on data from Schmidt and De Rosa (2018). It includes inputs such as fertilizer, diesel, land, irrigation, and outputs such as soybean production and main field emissions (ESM, Sect. 2.3.2). The input of land is linked with the global marginal market of land used to model iLUC (ESM, Sect. 2.2.7). According to Schmidt et al. (2015), there is a global market for land concerned with production capacity of land, instead of land area. Countries that supply land to this market are all countries that expand their arable land and countries that intensify their existing productive land. Thus, there is supply through expansion and

Table 2 Soybean yields with $(B . j-L C O)$ and without (Ref) the use of the inoculant. DayCent modelled yields are used in the LCIs (values in bold)

\begin{tabular}{|c|c|c|c|c|c|c|c|c|}
\hline \multicolumn{9}{|c|}{ Yields $\left[\mathrm{Mg}\right.$ dry matter $\mathrm{ha}^{-1}$ year $\left.^{-1}\right]$} \\
\hline \multicolumn{4}{|c|}{ Field trials (Leggett et al. 2017) } & \multirow{2}{*}{$\begin{array}{l}\text { Plot Analysis } \\
\text { Change in soybean } \\
\text { yield }(\%)\end{array}$} & \multicolumn{4}{|c|}{ Modelled by DayCent } \\
\hline Ref & B.j-LCO & $\begin{array}{l}\text { Change in yield } \\
(\Delta Q=B . j-L C O \\
- \text { Ref })\end{array}$ & $\begin{array}{l}\text { Change in soybean } \\
\text { yield }(\%)\end{array}$ & & Ref & B.j-LCO & $\begin{array}{l}\text { Change in yield } \\
(\Delta \mathrm{Q}=\mathrm{B} . \mathrm{j}-\mathrm{LCO} \\
- \text { Ref })\end{array}$ & $\begin{array}{l}\text { Change in } \\
\text { soybean yield } \\
(\%)\end{array}$ \\
\hline $2.55^{*}$ & $2.72 *$ & 0.17 & $+6.4 *$ & $+5.1 * *$ & $2.626(0.66)^{* * *}$ & $2.747(0.69)^{* * *}$ & 0.121 & +4.6 \\
\hline
\end{tabular}

\footnotetext{
*Corresponds to 9 provinces in Argentina

${ }^{* *}$ Corresponds to Buenos Aires, Argentina (number of plots $=58$ )

*** Arithmetic standard deviation
} 
intensification. In fact, the global market of land operates with different markets for land, i.e., (1) arable land, (2) intensive forest land, (3) extensive forest land, and (4) grassland. This delimits land types with different potential uses. Land use change (LUC) can be direct (dLUC) if the reference use of land is directly changed or indirect (iLUC) if it is induced via the market i.e. the use of land by the crop under study is what is considered as dLUC, while the supply of new land caused by the need for compensating the production capacity of the land required by the new demand is considered as iLUC. In our case, the avoided production of soybean in the global marginal market of soybean is linked to the global marginal market of land as it is expected for the marginal producers to avoid the need for new agricultural land.

\subsubsection{Downstream effect—soybean transport and drying}

Once harvested, the transport of soybeans from field to farm by tractor is added for both systems. Such transport has been calculated as the yield in wet weight times the distance from field to farm. Moisture at harvest is $13 \%$ and the distance field-farm is $14 \mathrm{~km}$ (ecoinvent v3.4. data for soybean production for Argentina). Similarly, the impact of transporting soybean from field to farm in the global marginal market of soybean, i.e., in Brazil and USA (needed for the substituted soybean production in the inoculant system) was calculated. The difference between the two systems covers the downstream effect of transport (ESM, Sect. 2.4.1).

For drying of additional and substituted soybean, moisture at storage was assumed to be $11 \%$ for all locations. For more details on the drying calculations, see the ESM, Sect. 2.4.2.

\subsubsection{Background processes}

All processes used in the background of the reference and inoculant systems are from the ecoinvent v3.4 database, consequential model (Wernet et al. 2016). The two background processes that are not drawn from this database are the global marginal market of soybean (Sect. 2.3.3) and the global marginal market of land used for iLUC modelling (ESM, Sect. 2.2.7, and Schmidt et al. 2015).

\subsubsection{Uncertainty analysis and sensitivity scenarios}

An uncertainty analysis was conducted to account for parameter uncertainty among which for DayCent emissions, yields, inoculant use and substituted soybean (see ESM, Sect. 5, for all details and Table 1). Pairwise Monte Carlo simulations are run, and based on these, we calculate the discernibility analysis count per impact and the statistical significance using a null hypothesis testing by means of a paired $t$-test, for all impacts as well. This analysis aims to show whether the mean of the relative impacts of two systems are significantly different from each other. For the sensitivity analysis, we performed the three oneat-the time scenarios: (1) 20- and 50-year annualized SOC emissions (as described by Kløverpris et al. 2020) instead of the time-independent approach, (2) higher impacts in the production of the inoculant to address the missing feedstocks in the inventory of this activity, and (3) excluding iLUC emissions that appeared as key contributors to the impacts (ESM, Sect. 4).

\subsection{Impacts not included in the LCA}

Two important environmental impacts are not explicitly quantified in this study and deserve further research: soil microflora and water impacts. Microbial inoculants can impact the soil microflora temporarily and in the long term, and these effects are still not well understood and need further research (Trabelsi and Mhamdi 2013). The effect of the inoculant, on synergistic effects, interactions and co-inoculation of $B . j-L C O$ and other microorganisms on soybean productivity has been studied (Chibeba et al. 2015; Egamberdieva et al. 2016; Meena et al. 2018). Also, the competitive behavior of the inoculant with indigenous microorganisms has been studied, finding that it can be used to enhance $\mathrm{N}$-fixation and productivity in organic soybean and may save chemical fertilizer use (AbouShanab et al. 2017). To our knowledge, no studies cover specifically the impacts of the use of $B . j-L C O$ inoculant on soil microflora and it would be an impact that needs further developments in LCA.

For water impacts, the development of bigger crops with higher yields will likely lead to higher evapotranspiration from the specific field and thereby a higher "green" water footprint (Mekonnen and Hoekstra 2011). In case the crops are fully rain-fed, this is not a major issue, e.g., in Buenos Aires soybean (Leggett et al. 2017). Also, higher yields due to the inoculant use avoid more soybean production elsewhere. Hence, the net water use is likely to be more or less unaffected per $\mathrm{Mg}$ of soybean produced, although this will depend on the efficiency of water use in the different locations. Besides irrigation water, some water is used in production of the inoculant (upstream effect). This is likely off-set by the water saved through the yield effect. We included the use of water in the inoculant production and no irrigation was assumed in the marginal producers of soybean. With data for specific locations, this impact could be added to the LCA impacts. 


\section{Results}

\subsection{Life cycle impact assessment results}

Table 3 shows the LCIA results per $\mathrm{kg}$ of inoculant as implemented in this study.

Table 4 shows the effects of introducing the inoculant in soybean cultivation for the 16 environmental impact categories considered. The total impacts for the reference system are shown for comparison as well as the relative changes in impacts caused by the inoculant. Impacts are reduced for all impact categories in the inoculant system with respect to the reference system. Among the four effects, the yield effect is dominating the impact reductions. The field effect also contributes to impact reductions, particularly of global warming, whereas upstream and downstream effects are relatively insubstantial.

Figure 3 shows the contribution of different activities to each impact category and each effect, for the two systems. Negative contributions (i.e., reduction of impacts) are shown for the avoided soybean production. These results correspond with the yield effect and are therefore only visible for the inoculant system. Field emissions are the only contributor to the field effect. The inoculant production contributes to the upstream effect and finally, drying and transport correspond with the downstream effect. More detailed results for the contribution analysis, contribution of effects and total impacts are available in the ESM, Sect. 3.1.

Table 3 LCIA of the production of one $\mathrm{kg}$ of inoculant for Stepwise impacts at mid-point level

\begin{tabular}{|c|c|c|}
\hline Impact category & Unit & Value per kg inoculant \\
\hline Human toxicity, carcinogens & $\mathrm{kg} \mathrm{C}_{2} \mathrm{H}_{3} \mathrm{Cl}_{-\mathrm{eq}}$ & $1.991 \mathrm{E}-02$ \\
\hline Human toxicity, non-carc. & $\mathrm{kg} \mathrm{C}_{2} \mathrm{H}_{3} \mathrm{Cl}_{-\mathrm{eq}}$ & $5.548 \mathrm{E}-03$ \\
\hline Respiratory inorganics & $\mathrm{kg}$ PM2.5 -eq & $2.974 \mathrm{E}-04$ \\
\hline Ionizing radiation & Bq C-14-eq & $7.084 \mathrm{E}-01$ \\
\hline Ozone layer depletion & $\mathrm{kg} \mathrm{CFC}-11_{-\mathrm{eq}}$ & $2.997 \mathrm{E}-08$ \\
\hline Ecotoxicity, aquatic & $\mathrm{kg} \mathrm{TEG}_{-\mathrm{eq}} \mathrm{w}$ & $1.014 \mathrm{E}+01$ \\
\hline Ecotoxicity, terrestrial & $\mathrm{kg} \mathrm{TEG}_{-\mathrm{eq}} \mathrm{s}$ & $1.594 \mathrm{E}+00$ \\
\hline Nature occupation & $\mathrm{PDF}^{*} \mathrm{~m}^{2} \mathrm{a}$ & $-8.375 \mathrm{E}-04$ \\
\hline Global warming & $\mathrm{kg} \mathrm{CO}_{2 \text {-eq }}$ & $3.523 \mathrm{E}-01$ \\
\hline Acidification & $\mathrm{m}^{2} \mathrm{UES}$ & $1.956 \mathrm{E}-02$ \\
\hline Eutrophication, aquatic & $\mathrm{kg} \mathrm{NO}_{3}^{-}$-eq & $3.534 \mathrm{E}-04$ \\
\hline Eutrophication, terrestrial & $\mathrm{m}^{2} \mathrm{UES}$ & $2.267 \mathrm{E}-02$ \\
\hline Respiratory organics & pers*ppm*h & $2.425 \mathrm{E}-04$ \\
\hline $\begin{array}{l}\text { Photochemical ozone, } \\
\text { vegetat. }\end{array}$ & $\mathrm{m}^{2} * \mathrm{ppm} * \mathrm{~h}$ & $2.431 \mathrm{E}+00$ \\
\hline Non-renewable energy & MJ primary & $1.143 \mathrm{E}+01$ \\
\hline Mineral extraction & MJ extra & $8.587 \mathrm{E}-03$ \\
\hline
\end{tabular}

\subsection{Sensitivity and uncertainty analysis results}

Here, we briefly describe key results for the sensitivity and uncertainty analysis. Detailed results can be found in the ESM, Sects. 4 and 5, respectively. For the first sensitivity scenario, field $\mathrm{CO}_{2}$ emissions related to changes in SOC are higher (less negative) than when estimated using the annualized approach. Therefore, global warming impacts are higher for the scenarios when the annualized estimates are used. Thus, the field effect increases (is less negative) and therefore the benefits of using the inoculant reduce. For the second scenario, the upstream effect is less than $15 \%$ of the total change in impacts, when the impacts per $\mathrm{kg}$ of inoculant are 10 times the initially established. These results suggest that including further feedstocks on the production of the inoculant would have to increase more than 10 times the impacts per $\mathrm{kg}$ of inoculant in order to meaningfully change the upstream effect. Finally results for the third sensitivity scenario show that all effects remain the same except for the yield effect that substantially increases (is less negative) because iLUC emissions ( $\mathrm{CO}_{2}$ emissions) are the largest contributor to this effect and have been excluded in the scenario. Global warming impacts reduce from around $7 \%$ when excluding iLUC to $4 \%$ when including iLUC.

For the uncertainty analysis the discernibility analysis shows that for all impacts (except for nature occupation), results are not discernible, meaning that when accounting for uncertainty it is difficult to assert whether the inoculant system has better results than the reference. Yet, results for the paired $t$-test show that for a $p$ value of $5 \%$ and a corrected $p$ value of $2.9 \%, 16$ out of 16 impacts are significantly different. This means that the mean of the distribution of the difference of impacts between reference and inoculant systems, are significantly different from zero which is the hypothesized mean, and therefore impacts are significantly reduced in the inoculant system compared to the reference.

\section{Discussion}

\subsection{Effects discussion}

Results showed that the field and yield effects are the largest contributors to the overall benefits of using the inoculant in soybean grown with corn as previous crop. Upstream and downstream effects contribute insubstantially to the change in impacts from introducing the inoculant.

The field effect depends entirely on changes in soil emissions from the area A as modelled in DayCent, because emissions related to iLUC, field work, fertilizer, pesticides, seeds, and other inputs do not change between the systems for the area A. The field effect is negative (reduced impacts) 
Table 4 Effects of the use of inoculant on the impacts of soybean production per Mg soybean. Negative values refer to improvement compare to the reference

\begin{tabular}{|c|c|c|c|c|c|c|c|c|}
\hline Impact category & Unit & $\begin{array}{l}\text { Upstream } \\
\text { effect (Eq. 1) }\end{array}$ & $\begin{array}{l}\text { Field effect } \\
\text { (Eq. 2) }\end{array}$ & $\begin{array}{l}\text { Yield effect } \\
\text { (Eq. 3) }\end{array}$ & $\begin{array}{l}\text { Down-stream } \\
\text { effect (Eq. 4) }\end{array}$ & $\begin{array}{l}\text { Total inoculant } \\
\text { effect (Eq. 5) }\end{array}$ & $\begin{array}{l}\text { Total ref. without } \\
\text { inoculant incl. } \\
\text { iLUC }\end{array}$ & $\begin{array}{l}\text { Changewith } B . j- \\
L C O \text { versus ref } \\
\text { incl. iLUC (\%) }\end{array}$ \\
\hline $\begin{array}{l}\text { Human toxicity, } \\
\text { carcinogens }\end{array}$ & $\mathrm{kg} \mathrm{C}_{2} \mathrm{H}_{3} \mathrm{Cl}_{-\mathrm{eq}}$ & $1.14 \mathrm{E}-03$ & $0.00 \mathrm{E}+00$ & $-2.21 \mathrm{E}-01$ & $1.86 \mathrm{E}-03$ & $-2.18 \mathrm{E}-01$ & $5.53 \mathrm{E}+00$ & $-4.0 \%$ \\
\hline $\begin{array}{l}\text { Human toxicity, } \\
\text { non-carc. }\end{array}$ & $\mathrm{kg} \mathrm{C}_{2} \mathrm{H}_{3} \mathrm{Cl}_{\text {-eq }}$ & $3.19 \mathrm{E}-04$ & $1.94 \mathrm{E}-04$ & $-2.24 \mathrm{E}-01$ & $6.39 \mathrm{E}-03$ & $-2.17 \mathrm{E}-01$ & $1.14 \mathrm{E}+01$ & $-1.9 \%$ \\
\hline $\begin{array}{l}\text { Respiratory } \\
\text { inorganics }\end{array}$ & $\mathrm{kg}$ PM2.5 -eq & $1.71 \mathrm{E}-05$ & $4.62 \mathrm{E}-04$ & $-3.36 \mathrm{E}-02$ & $2.07 \mathrm{E}-03$ & $-3.10 \mathrm{E}-02$ & $1.19 \mathrm{E}+00$ & $-2.6 \%$ \\
\hline Ionizing radiation & Bq C-14-eq & $4.07 \mathrm{E}-02$ & $0.00 \mathrm{E}+00$ & $-1.71 \mathrm{E}+01$ & $1.40 \mathrm{E}-01$ & $-1.70 \mathrm{E}+01$ & $3.59 \mathrm{E}+02$ & $-4.7 \%$ \\
\hline $\begin{array}{c}\text { Ozone layer } \\
\text { depletion }\end{array}$ & $\mathrm{kg} \mathrm{CFC}-11_{\text {-eq }}$ & $1.72 \mathrm{E}-09$ & $0.00 \mathrm{E}+00$ & $-1.24 \mathrm{E}-06$ & $5.91 \mathrm{E}-09$ & $-1.23 \mathrm{E}-06$ & $2.70 \mathrm{E}-05$ & $-4.6 \%$ \\
\hline $\begin{array}{l}\text { Ecotoxicity, } \\
\text { aquatic }\end{array}$ & $\mathrm{kg} \mathrm{TEG}_{-\mathrm{eq}} \mathrm{w}$ & $5.83 \mathrm{E}-01$ & $1.49 \mathrm{E}-02$ & $-6.14 \mathrm{E}+02$ & $5.35 \mathrm{E}+00$ & $-6.09 \mathrm{E}+02$ & $8.79 \mathrm{E}+03$ & $-6.9 \%$ \\
\hline $\begin{array}{l}\text { Ecotoxicity, ter- } \\
\text { restrial }\end{array}$ & $\mathrm{kg} \mathrm{TEG}_{-\mathrm{eq}} \mathrm{s}$ & $9.17 \mathrm{E}-02$ & $3.73 \mathrm{E}-02$ & $-5.33 \mathrm{E}+01$ & $8.35 \mathrm{E}-01$ & $-5.24 \mathrm{E}+01$ & $1.48 \mathrm{E}+03$ & $-3.5 \%$ \\
\hline Nature occupation & $\mathrm{PDF}^{*} \mathrm{~m}^{2} \mathrm{a}$ & $-4.82 \mathrm{E}-05$ & $0.00 \mathrm{E}+00$ & $-4.41 \mathrm{E}+01$ & $-1.78 \mathrm{E}-02$ & $-4.41 \mathrm{E}+01$ & $1.34 \mathrm{E}+03$ & $-3.3 \%$ \\
\hline Global warming & $\mathrm{kg} \mathrm{CO}_{2 \text {-eq }}$ & $2.03 \mathrm{E}-02$ & $-6.06 \mathrm{E}+00$ & $-3.97 \mathrm{E}+01$ & $2.09 \mathrm{E}-01$ & $-4.56 \mathrm{E}+01$ & $1.12 \mathrm{E}+03$ & $-4.1 \%$ \\
\hline Acidification & $\mathrm{m}^{2} \mathrm{UES}$ & $1.12 \mathrm{E}-03$ & $1.14 \mathrm{E}-01$ & $-5.70 \mathrm{E}+00$ & $1.84 \mathrm{E}-02$ & $-5.56 \mathrm{E}+00$ & $1.84 \mathrm{E}+02$ & $-3.0 \%$ \\
\hline $\begin{array}{l}\text { Eutrophication, } \\
\text { aquatic }\end{array}$ & $\mathrm{kg} \mathrm{NO}_{3}^{-}{ }^{-}$-eq & $2.03 \mathrm{E}-05$ & $2.18 \mathrm{E}-02$ & $-1.63 \mathrm{E}+00$ & $4.69 \mathrm{E}-05$ & $-1.61 \mathrm{E}+00$ & $3.52 \mathrm{E}+01$ & $-4.6 \%$ \\
\hline $\begin{array}{l}\text { Eutrophication, } \\
\text { terrestrial }\end{array}$ & $\mathrm{m}^{2} \mathrm{UES}$ & $1.30 \mathrm{E}-03$ & $5.33 \mathrm{E}-01$ & $-2.45 \mathrm{E}+01$ & $2.09 \mathrm{E}-02$ & $-2.39 \mathrm{E}+01$ & $8.14 \mathrm{E}+02$ & $-2.9 \%$ \\
\hline $\begin{array}{l}\text { Respiratory } \\
\text { organics }\end{array}$ & pers*ppm*h & $1.39 \mathrm{E}-05$ & $-1.45 \mathrm{E}-04$ & $-5.98 \mathrm{E}-03$ & $1.13 \mathrm{E}-04$ & $-6.00 \mathrm{E}-03$ & $2.88 \mathrm{E}-01$ & $-2.1 \%$ \\
\hline $\begin{array}{l}\text { Photochemical } \\
\text { ozone, vegetat. }\end{array}$ & $\mathrm{m}^{2 *} \mathrm{ppm} * \mathrm{~h}$ & $1.40 \mathrm{E}-01$ & $-1.18 \mathrm{E}+00$ & $-7.44 \mathrm{E}+01$ & $1.33 \mathrm{E}+00$ & $-7.41 \mathrm{E}+01$ & $3.49 \mathrm{E}+03$ & $-2.1 \%$ \\
\hline $\begin{array}{l}\text { Non-renewable } \\
\text { energy }\end{array}$ & MJ primary & $6.57 \mathrm{E}-01$ & $0.00 \mathrm{E}+00$ & $-1.51 \mathrm{E}+02$ & $2.29 \mathrm{E}+00$ & $-1.48 \mathrm{E}+02$ & $3.56 \mathrm{E}+03$ & $-4.1 \%$ \\
\hline $\begin{array}{l}\text { Mineral extrac- } \\
\text { tion }\end{array}$ & MJ extra & $4.93 \mathrm{E}-04$ & $0.00 \mathrm{E}+00$ & $-7.77 \mathrm{E}-01$ & $6.07 \mathrm{E}-03$ & $-7.70 \mathrm{E}-01$ & $2.05 \mathrm{E}+01$ & $-3.8 \%$ \\
\hline
\end{tabular}

for three impacts: global warming, respiratory organics, and photochemical ozone formation impact on vegetation. Other impacts have a positive field effect, i.e., the inoculant use does not lead to reductions compared to the reference. A closer look at global warming, for instance, shows that $\mathrm{N}_{2} \mathrm{O}$ emissions from the area $\mathrm{A}$ have the largest increase with the use of the inoculant and SOC-related $\mathrm{CO}_{2}$ emissions the largest reduction, leading to a net reduction in greenhouse gas (GHG) emissions from the area A (ESM, Table 17). $\mathrm{N}_{2} \mathrm{O}$ and $\mathrm{SOC}$ emissions/sinks are influenced by the increase in biomass (plant and root growth) stimulated by the inoculant and modeled in DayCent, not just for soybeans but also for corn. The slight increase in corn yield over the 100-year simulation period increases the return of carbon and nitrogen to the soil via plant inputs, as a consequence this induces additional carbon storage and nitrogen-related emissions. Because these results for the field effect depend entirely on the DayCent model outputs, uncertainties, and limitations of this modelling approach are further discussed (Sect. 4.2).

The yield effect is the largest contributor among the effects. The yield effect is negative for all impact categories by definition as it consists of avoiding the impacts of soybean production in the global marginal market of soybean. The larger the yield increase in the inoculant system compared to the reference, the more impacts will be avoided and the more negative the yield effect will be (direct proportionality). These results depend primarily on the yield change between systems, which is based on experimental data from Leggett et al. (2017) and also on how this change was captured in DayCent (see Sect. 4.2 for limitations). Also, the benefit of avoiding soybean produced in this market is larger when accounting for iLUC $\left(0.86 \mathrm{~kg} \mathrm{CO}_{2 \mathrm{eq}} \mathrm{Mg}^{-1}\right.$ soybean) compared to when not, i.e., excluding iLUC $\left(0.24 \mathrm{~kg} \mathrm{CO}_{2 \text { eq }}\right.$ $\mathrm{Mg}^{-1}$ soybean). $\mathrm{N}_{2} \mathrm{O}$ and $\mathrm{CO}_{2}$ emissions from iLUC are the two main contributors to total GHG emissions of avoided soybean production in this market (ESM, Table 17). iLUC modeling is thus important as are its limitations and uncertainties, for instance data and identification of marginal land. More strengths and weaknesses of the model are discussed, also in comparison to other iLUC models, in De Rosa et al. (2016). Among the most important strength is the suitability of the model to be used within an LCA framework. For instance, there is no conflict with the usual assumption of full price elasticity in the markets (Weidema 2003), and the 


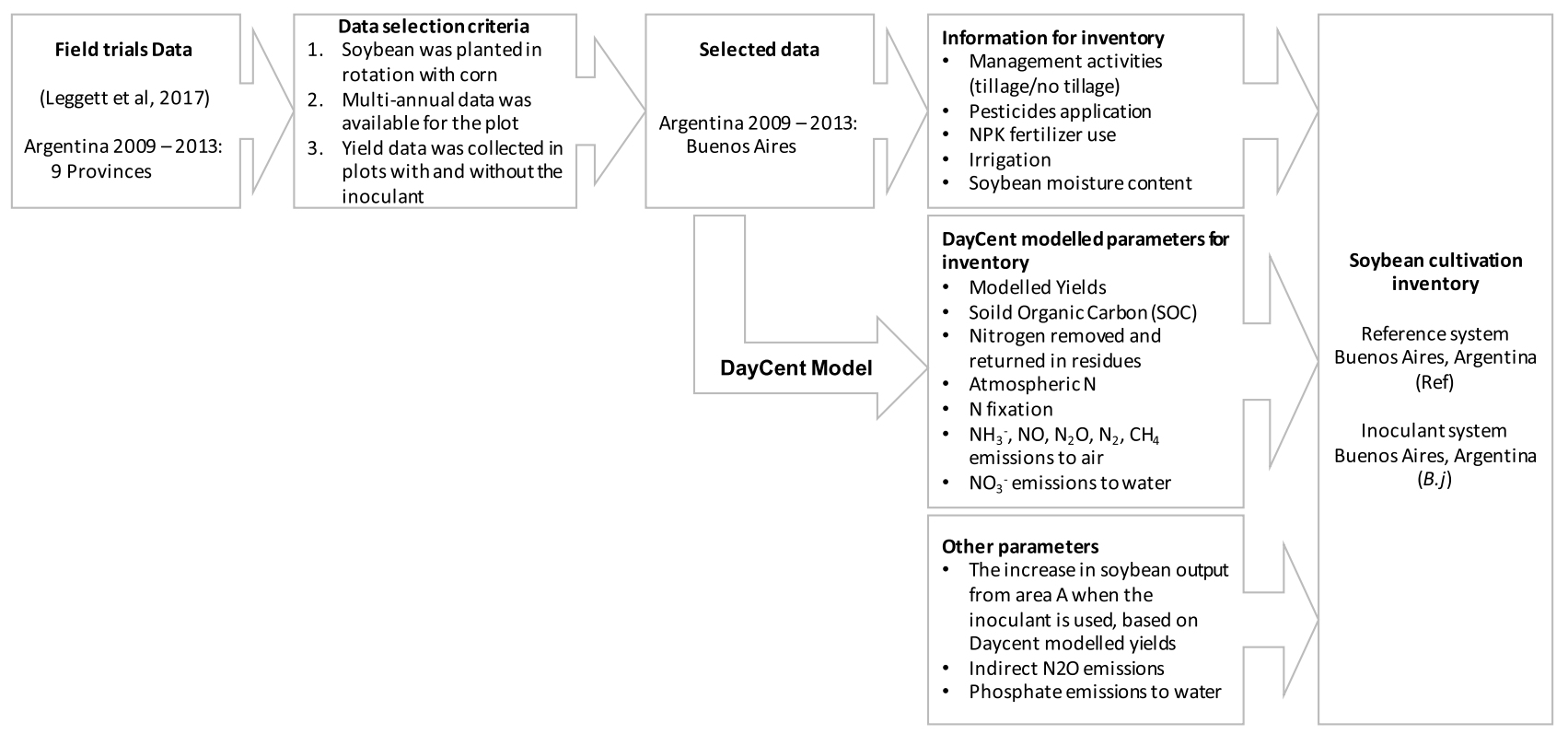

Fig. 1 Data flows from field trials to life cycle inventories of reference and inoculant systems

accounting for land use emissions over time is being handled by means of the global warming potential (GWP) concept in line with the characterization of greenhouse gases usually applied in LCA.

The displacement of marginal soybean production in Brazil and the USA is important as much of the overall environmental benefits of the inoculant are driven by this effect. It is hence warranted to pay further attention to American soybean markets. Studies show that the largest producers of soybean namely Brazil, USA, and Argentina, affect one another when changing their production as a consequence of price and demand changes (Plato and Chambers 2004; Boerema et al. 2016; Yao et al. 2018). For instance, an increased supply in South America reduces the soybean price in the USA (Plato and Chambers 2004). This suggests that increased supply in Argentina may change production in Brazil and USA, but how production will change depends not only on the price change but also on the demand, on production costs, as well as on the stimulus for farmers to remain producing soybean at a lower market price, among others. Capturing such complexities and better estimating the short-term effects that additionally produced soybean in Argentina will have on the global market and marginal producers, would require more sophisticated economic modelling, for instance by a partial-equilibrium model. Such modelling can better inform the assumptions made for the system expansion, i.e., determining the marginal producers and the effect that additionally produced soybean will have in the global marginal market; thus, this is a matter for further research. Yet, we believe the system expansion presented here is plausible and representative of the dynamics of the global soybean market.
The upstream effect is positive for all impacts because producing the inoculant is associated with an impact (in the inoculant system) that is not part of the reference system. Although the inoculant production inventory covers most materials, transport, energy, and emissions reported by Novozymes, three relevant materials are not included due to lack of available relevant inventories for these materials. A sensitivity scenario is explored to account for the possible effect of these inventories (ESM, Sect. 4). The scenario confirms the relatively small contribution of this effect compared to the other effects.

Finally, the downstream effect was either positive or negative depending on the impact and the location. For transport, we assumed the same distance from field to farm for all locations thus the difference in impacts reflects only the difference in yields. Similarly, for drying we assumed the same moisture content of soybean in all countries; thus, the difference in impacts only reflects the difference in yields. Estimates of the downstream effect would improve with more location representative data on soybean moisture and distances from field to farm.

\subsection{DayCent uncertainties and limitations}

There are uncertainties and limitations around the replication of the inoculant action on soybean, as observed in the field, within DayCent. The main assumption made is that the inoculant only impacts soybean yield. This assumption could lead to misrepresentations of some observed field behavior and thus of the modelled emissions. For instance, the field trial dataset reports yield and yield changes induced 

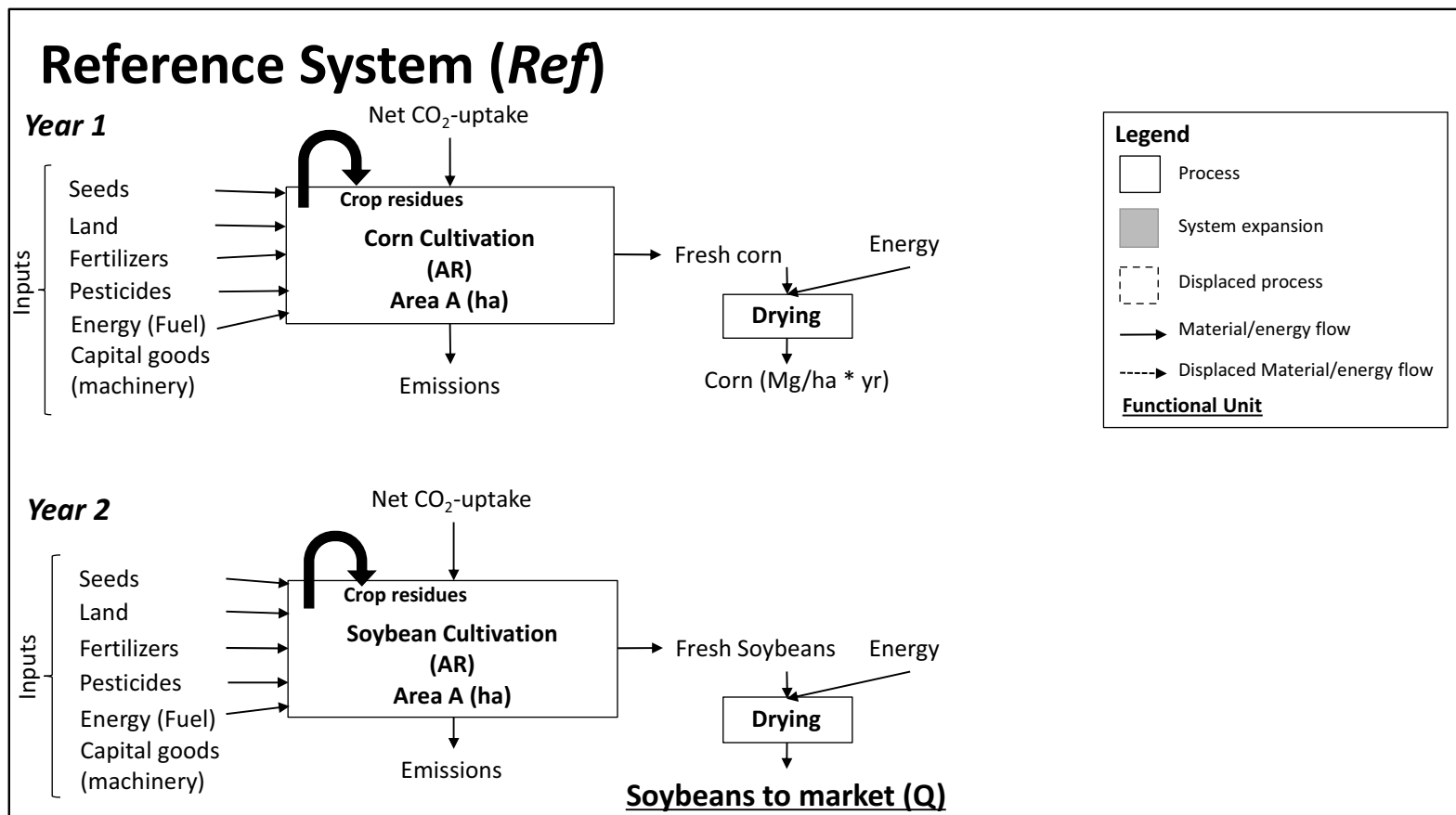

\section{Inoculant System (B.j-LCO)}

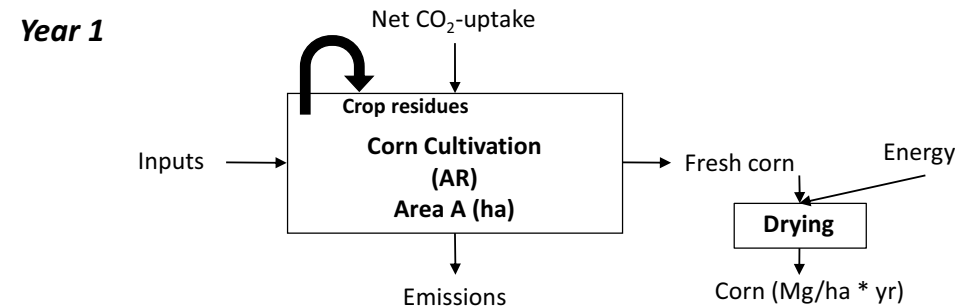

Year 2
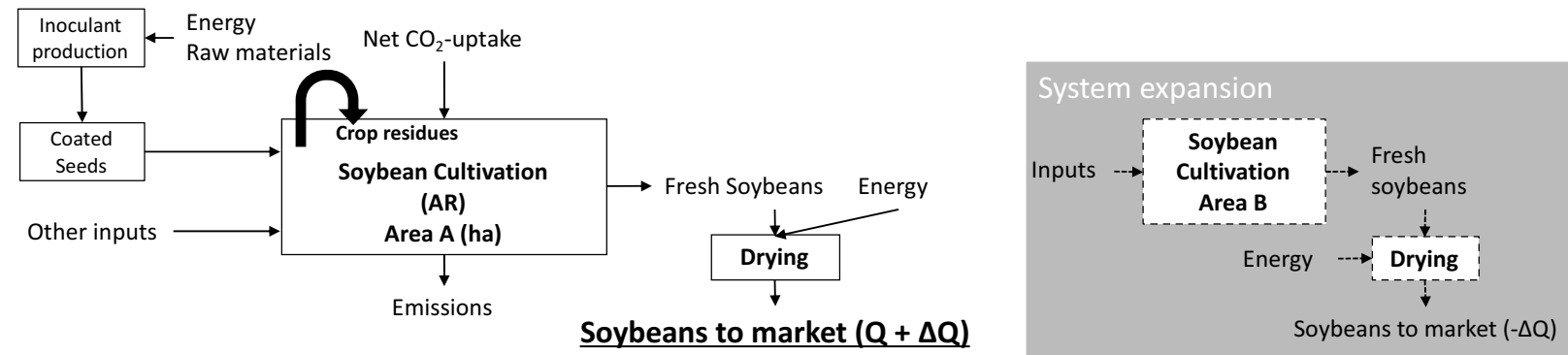

Fig. 2 Reference (Ref) and the inoculant (B.j-LCO) systems for soybean production in a corn-soybean rotation

by the inoculant use. From the two, DayCent simulations in this study reflect yield changes, misrepresenting, e.g., long-term soil or crop processes indirectly induced due to the presence of the inoculant. Also, as detailed in Leggett et al. (2017), the presence of the inoculant does not trigger a unique response by the soybean crop. Yet, yield responses to the inoculant within DayCent modelling in this study, indicated an increase in yield always, possibly misrepresenting years where the yield decreased, as it reached its genetic maximum (Leggett et al. 2017). In the absence of 


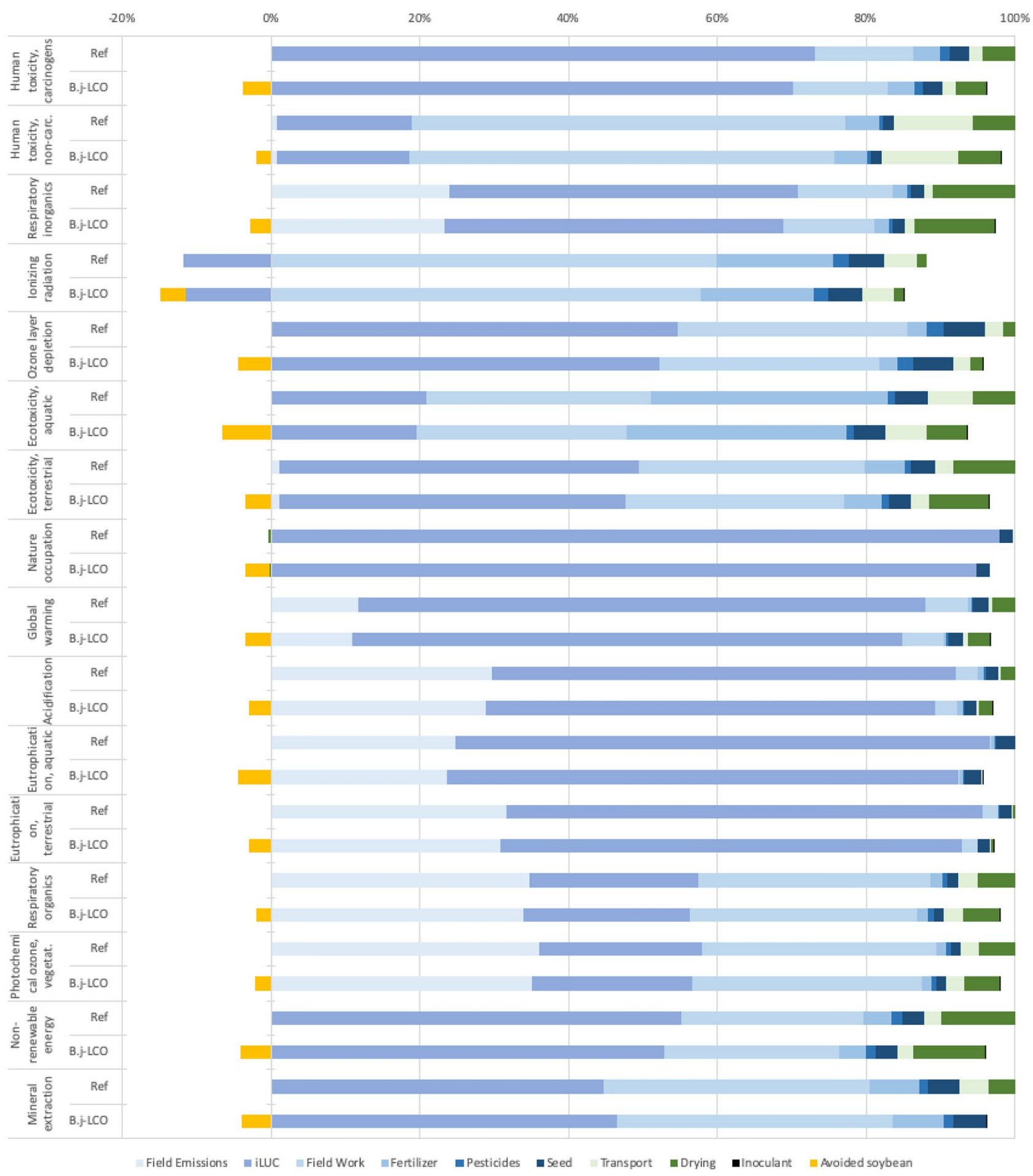

Fig. 3 Contribution analysis of the impacts of soybean production with (B.j-LCO) and without (Ref) the inoculant. A negative contribution means a reduction of the impact. The field effect includes impacts from (in blue): field emissions, iLUC, field work, fertilizers, pesticides and seeds; the downstream effect includes impacts from (in green) transport and drying; the yield effect includes impacts from the avoided soybean (in yellow) and the upstream effect includes impacts from the inoculant (in black)

more detailed experimental information that could be used for model parameterizations and upgrade model predictions, the approach adopted here is valid in providing an understanding of the impact caused by the inoculant on emissions as the assumptions underpinning model simulations and implementation are in line with established 
modelling methodologies outlined in other studies (Fitton et al. 2017). Besides, we expect that using yield changes as the key DayCent model driver could represent well the interactions between the inoculant, the plant, the yields and hence the modelled emissions because of model-intercomparing studies (Fitton et al. 2019), that show that outputs from DayCent matched both the emissions field-data and also data for more complex models that could explicitly model the relationship examined.

Moreover, the method used here to implement yield changes within DayCent is also uncertain. As the inoculant aims to promote the uptake of $\mathrm{N}$ from the soil by the soybean plant, replication of this effect was undertaken by modifying the maximum amount of $\mathrm{N}$ fixed per gram of $\mathrm{C}$ fixed via net primary production (NPP) if there is insufficient $\mathrm{N}$ within the soil. Gradual increase of this parameter was used to characterize the effect the inoculant has on plant $\mathrm{N}$ uptake in DayCent. All other inputs such as soil, climate, management including fertilization, chemical treatment and residue production and treatment, and corn and soybean growth parameters remained constant. Thus, only one parameter change represents the inoculant mode of action. A limitation of this approach is that it was not possible to achieve the exact percentage change in yield observed on the field, and values presented in this analysis are based on the closest long-term match. Moreover, other parameters could change in reality due to the effect of the inoculant, and thus, they could be misrepresented by the approach leading to a misrepresentation of emissions too, as discussed for the field effect. Additional field data on such parameters could help improve this limitation.

\subsection{LCA uncertainty and sensitivities}

Results of the uncertainty analysis confirm the improvements in soybean cultivation impacts due to the inoculant use including parametric uncertainty. No trade-offs appear, i.e., 16 out of 16 impact categories are significantly lower in the inoculant system when accounting for uncertainty.

The results to the three scenarios can be found in ESM, Sect. 4. The first scenario shows that annualized approaches to calculate SOC emissions lead to lower benefits in global warming impacts than the time-independent approach. Thus, the field effect increases and therefore the benefits of using the inoculant reduce if the annualized approach is used. The second scenario was already discussed in Sect. 3.1. The third scenario shows that all effects remain the same except for the yield effect that substantially increases as iLUC emissions are the main contributor to this effect, i.e., $\mathrm{CO}_{2}$ emissions from iLUC. Particularly, Brazil has a high conversion rate of forests into arable land mainly for cattle ranching and more recently for soybean cultivation (Boerema et al. 2016).

\subsection{Rough perspectives for inoculant use in all Argentinian soybean production}

The average production of soybeans in Argentina from 2015 to 2018 was 53 million metric tons (FAO 2020). The inoculant is currently used on 5.5\% of Argentinian soybean fields but is expected to have the potential to give a yield response on $80 \%$ of these fields if applied at full scale (D'Alessio 2020). If the inoculant were applied at this scale, the global warming benefit would correspond to a reduction in greenhouse gas emissions of 1.9 million $\mathrm{Mg} \mathrm{CO}_{2}$ e [i.e., $80 \%$, 53 million $\mathrm{Mg} 45.6 \mathrm{~kg} \mathrm{CO}_{2} \mathrm{e} \mathrm{Mg}^{-1}$ ]. While this is a rough extrapolation of the results for the Buenos Aires province to the rest of the country, it gives an indication of total benefits the inoculant could potentially provide (order of magnitude). An important assumption behind these estimates is an increasing demand of soybean. Since mid-1990s, imports of soybean by China, the largest world importer, have been increasing. Nonetheless, in the last couple of years, imports by China show a more stable behavior (FAO 2021) so this may be an assumption to revise for the short-term future.

\section{Conclusions}

We compared the life cycle environmental impacts of soybean cultivation with and without the use of an inoculant containing Bradyrhizobium japonicum and the signal molecule lipochitooligosaccharide (LCO) in the Buenos Aires province of Argentina. This cradle-to-gate assessment included the cultivation of soybean, the inoculant production, and the postharvest activities including transport from field to farm and drying of soybean until ready for market.

The environmental benefits from introducing the inoculant were assessed by investigating the effect of this inoculant in four main stages. The upstream effect covers the inoculant production. The field effect consists of the change in field emissions triggered by the increased production per ha in the inoculant system. The yield effect accounts for the fact that additional production in the inoculant system is expected to replace soybean production in the global marginal market of soybean and its linked impacts. The downstream effect compares the postharvest impacts of the additional production in the inoculant system and in soybean production elsewhere (avoided).

The inoculant use in soybean production in Buenos Aires, Argentina, reduced all studied environmental impacts. Hence, the use of this inoculant leads to overall environmental benefits and no trade-offs. This is a key finding contributing to knowledge about environmental impacts emerging from inoculants' use. The main contributor to this benefit is the yield effect. Most of these avoided impacts come from iLUC $\mathrm{CO}_{2}$ emissions, which result from the assumed system 
expansion. Avoiding soybean production in Brazil and USA is crucial for the environmental benefits found in this study. Hence, the marginal soybean producers and the effect of the additional production of soybean induced by the inoculant use should be carefully determined and is a matter for further research. The field effect is the second largest contributor to the overall reduction in GHG emissions, mostly due to the effect of the increased SOC activated by the inoculant use, as modelled by DayCent in this study. DayCent results carry uncertainties and limitations of modelling the mode of action of the inoculant given the parametrization of the model. In the absence of field data to better model emissions and dynamics of nutrients in DayCent, uncertainties remain, and these results represent a modelling explorative exercise valid to understand possible dynamics and environmental impacts driven by the inoculant use. The downstream and upstream effects contribute insubstantially to the total change in impacts when using the inoculant. These conclusions hold for this particular inoculant used in the province of Buenos Aires, Argentina, in a corn-soybean rotation.

Some of the limitations of this study and topics for further research that could further refine calculations and help improve the robustness of conclusions include addressing missing data on the supply chains of some feedstocks to produce the inoculant, further study of the assumption of avoided soybean production taking place at the global marginal market of soybean which could be tested with more sophisticated economic models, additional field data collection to better parameterize modelled field emissions in DayCent, field data collection on the residues production and treatment, and including uncertainty of iLUC emissions. Finally, other impacts such as water, biodiversity and microflora impacts should also be considered in order to have more complete environmental assessments of inoculants use, with broader focus besides productivity gains.

Supplementary information The online version contains supplementary material available at https://doi.org/10.1007/s11367-021-01929-7.

\section{Declarations}

Conflict of interest Jesper H. Kløverpris is employed by Novozymes who produce and market microbial inoculants as part of a larger portfolio of biological solutions. Claus Nordstrøm Scheel was employed by Novozymes when the study was conducted.

Open Access This article is licensed under a Creative Commons Attribution 4.0 International License, which permits use, sharing, adaptation, distribution and reproduction in any medium or format, as long as you give appropriate credit to the original author(s) and the source, provide a link to the Creative Commons licence, and indicate if changes were made. The images or other third party material in this article are included in the article's Creative Commons licence, unless indicated otherwise in a credit line to the material. If material is not included in the article's Creative Commons licence and your intended use is not permitted by statutory regulation or exceeds the permitted use, you will need to obtain permission directly from the copyright holder. To view a copy of this licence, visit http://creativecommons.org/licenses/by/4.0/.

\section{References}

Abodeely J, Muth D, Bryden KM (2012) Integration of the DAYCENT biogeochemical model within a multi-model framework. In: iEMSs 2012 - Managing Resources of a Limited Planet: Proceedings of the 6th Biennial Meeting of the International Environmental Modelling and Software Society

Abou-Shanab RAI, Wongphatcharachai M, Sheaffer CC et al (2017) Competition between introduced Bradyrhizobium japonicum strains and indigenous bradyrhizobia in Minnesota organic farming systems. Symbiosis 73:155-163. https://doi.org/10.1007/s13199-017-0505-4

Adesemoye AO, Kloepper JW (2009) Plant-microbes interactions in enhanced fertilizer-use efficiency. Appl Microbiol Biotechnol 85:1-12. https://doi.org/10.1007/s00253-009-2196-0

Alori ET, Babalola OO (2018) Microbial Inoculants for Improving Crop Quality and Human Health in Africa. Front Microbiol. https://doi.org/10.3389/fmicb.2018.02213

Alves BJR, Boddey RM, Urquiaga S (2003) The success of BNF in soybean in Brazil. Plant Soil 252:1-9. https://doi.org/10.1023/A: 1024191913296

Andrews M, James EK, Cummings SP et al (2003) Use of nitrogen fixing bacteria inoculants as a substitute for nitrogen fertiliser for dryland graminaceous crops: progress made, mechanisms of action and future potential. In: Symbiosis

Backer R, Rokem JS, Ilangumaran G et al (2018) Plant growth-promoting rhizobacteria: Context, mechanisms of action, and roadmap to commercialization of biostimulants for sustainable agriculture. Front Plant Sci 871:1-17. https://doi.org/10.3389/fpls.2018.01473

Boerema A, Peeters A, Swolfs S et al (2016) Soybean trade: balancing environmental and socio-economic impacts of an intercontinental market. PLoS One 11:e0155222. https://doi.org/10.1371/journal. pone. 0155222

Chibeba AM, Guimarães MDF, Brito OR et al (2015) Co-inoculation of soybean with Bradyrhizobium and Azospirillum promotes early nodulation. Am J Plant Sci 6:1641-1649

D’Alessio (2020) Senior manager: Personal communication. Novozymes

Dalgaard R, Halberg N, Kristensen IS, Larsen I (2006) Modelling representative and coherent Danish farm types based on farm accountancy data for use in environmental assessments. Agric Ecosyst Environ 117:223-237. https://doi.org/10.1016/j.agee. 2006.04.002

De Klein C, Novoa RSA, Ogle S, Smith KA, Rochette P, Wirth, TC, McConkey BG, Mosier A, Rypdal K, Walsh M, Williams SA (2006) IPCC Guidelines for National GHG Inventories. Chapter 11: N2O Emissions From Managed Soils, and CO2 Emissions From Lime and Urea Application

De Rosa M, Knudsen MT, Hermansen JE (2016) A comparison of land use change models: challenges and future developments. J Clean Prod 113:183-193. https://doi.org/10.1016/j.jclepro.2015.11.097

Del Grosso SJ, Parton WJ, Mosier AR et al (2006) DAYCENT National-Scale Simulations of Nitrous Oxide Emissions from Cropped Soils in the United States. J Environ Qual 35:1451-1460. https://doi.org/10.2134/jeq2005.0160

Del Grosso SJ, Parton WJ, Mosier AR, et al (2001) Simulated interaction of carbon dynamics and nitrogen trace gas fluxes using the DAYCENT model. In: Schaffer M, Hansen LM (eds) Modeling carbon and nitrogen dynamics for soil management. CRC press, Boca Raton, Florida 
Di Benedetto NA, Corbo MR, Campaniello D et al (2017) The role of Plant Growth Promoting Bacteria in improving nitrogen use efficiency for sustainable crop production: a focus on wheat. AIMS Microbiol 3:413-434. https://doi.org/10.3934/microbiol.2017.3.413

Egamberdieva D, Jabborova D, Berg G (2016) Synergistic interactions between Bradyrhizobium japonicum and the endophyte Stenotrophomonas rhizophila and their effects on growth, and nodulation of soybean under salt stress. Plant Soil 405:35-45. https://doi.org/10. 1007/s11104-015-2661-8

FAO (2018) FAOSTAT. Food and Agriculture Organisation of the United Nations. http://faostat.fao.org/. Accessed 20 Jul 2003

FAO (2020) FAOSTAT. Food and Agriculture Organisation of the United Nations. http://faostat.fao.org

FAO (2021) FAOSTAT. Food and Agriculture Organization of the United Nations. http://faostat.fao.org/. Accessed 15 Mar 2021

Fitton N, Bindi M, Brilli L et al (2019) Modelling biological N fixation and grass-legume dynamics with process-based biogeochemical models of varying complexity. Eur J Agron 106:58-66. https://doi. org/10.1016/j.eja.2019.03.008

Fitton N, Datta A, Cloy JM et al (2017) Modelling spatial and interannual variations of nitrous oxide emissions from UK cropland and grasslands using DailyDayCent. Agric Ecosyst Environ 250:1-11. https://doi.org/10.1016/j.agee.2017.08.032

Fitton N, Datta A, Hastings A et al (2014) The challenge of modelling nitrogen management at the field scale: simulation and sensitivity analysis of $\mathrm{N} 2 \mathrm{O}$ fluxes across nine experimental sites using DailyDayCent. Environ Res Lett. https://doi.org/10.1088/1748-9326/9/9/095003

Foley JA, Ramankutty N, Brauman KA et al (2011) Solutions for a cultivated planet. Nature 478:337

Godfray HCJ, Beddington JR, Crute IR et al (2010) Food security: the challenge of feeding 9 billion people. Science (80- ) 327:812-8. https://doi.org/10.1126/science.1185383

Hauschild MZ, Potting J (2005) Spatial Differentiation in Life Cycle Assessment: The EDIP2003 Methodology. Copenhagen

Horrigan L, Lawrence RS, Walker P (2002) How sustainable agriculture can address the environmental and human health harms of industrial agriculture. Environ Health Perspect 110:445-456. https://doi.org/10. 1289/ehp.02110445

ISO (2006) ISO 14044. Environmental management - Life cycle assessment - Requirements and guidelines. Switzerland

Jolliet O, Margni M, Charles R et al (2003) IMPACT 2002+: A new life cycle impact assessment methodology. Int J Life Cycle Assess 8:324. https://doi.org/10.1007/BF02978505

Keyser HH, Li F (1992) Potential for increasing biological nitrogen fixation in soybean. In: Ladha JK, George T, Bohlool BB (eds) Biological Nitrogen Fixation for Sustainable Agriculture. Developments in Plant and Soil Sciences. Springer, Dordrecht, The Netherlands

Kløverpris JH, Scheel CN, Schmidt J et al (2020) Assessing life cycle impacts from changes in agricultural practices of crop production. Int J Life Cycle Assess 25:1991-2007. https://doi.org/10.1007/ s11367-020-01767-z

Leggett M, Diaz-Zorita M, Koivunen M et al (2017) Soybean Response to Inoculation with Bradyrhizobium japonicum in the United States and Argentina. Agron J 109:1031-1038. https://doi.org/10.2134/ agronj2016.04.0214

Leggett M, Newlands NK, Greenshields D, West L, Inman S, Koivunen, ME (2015) Maize yield response to a phosphorus-solubilizing microbial inoculant in field trials. J Agric Sci. https://doi.org/10. 1017/S0021859614001166

Meena RS, Vijayakumar V, Yadav GS, Mitran T (2018) Response and interaction of Bradyrhizobium japonicum and arbuscular mycorrhizal fungi in the soybean rhizosphere. Plant Growth Regul 84:207223. https://doi.org/10.1007/s10725-017-0334-8

Mekonnen MM, Hoekstra AY (2011) The green, blue and grey water footprint of crops and derived crop products. Hydrol Earth Syst Sci 15:1577-1600. https://doi.org/10.5194/hess-15-1577-2011
Nadeem SM, Naveed M, Zahir ZA, Asghar HN (2013) Plant-microbe interactions for sustainable agriculture: fundamentals and recent advances. In: Arora NK (ed) Plant microbe symbiosis: fundamentals and advances. Springer India, New Delhi, p 459

Oldfield EE, Bradford MA, Wood SA (2019) Global meta-analysis of the relationship between soil organic matter and crop yields. Soil 5:15-32. https://doi.org/10.5194/soil-5-15-2019

Parton WJ, Holland EA, Del Grosso SJ et al (2001) Generalized model for $\mathrm{NO} x$ and $\mathrm{N} 2 \mathrm{O}$ emissions from soils. J Geophys Res Atmos 106:17403-17419. https://doi.org/10.1029/2001JD900101

Petersen BM, Knudsen MT, Hermansen JE, Halberg N (2013) An approach to include soil carbon changes in life cycle assessments. J Clean Prod 52:217-224. https://doi.org/10.1016/j.jclepro.2013.03.007

Plato GE, Chambers W (2004) How does structural change in the global soybean market affect the U.S. price?

Rockström J, Williams J, Daily G et al (2017) Sustainable intensification of agriculture for human prosperity and global sustainability. Ambio. https://doi.org/10.1007/s13280-016-0793-6

Santos MS, Nogueira MA, Hungria M (2019) Microbial inoculants: reviewing the past, discussing the present and previewing an outstanding future for the use of beneficial bacteria in agriculture. AMB Express 9:205. https://doi.org/10.1186/s13568-019-0932-0

Schmidt J, Brandão M (2013) LCA screening of biofuels - iLUC, biomass manipulation and soil carbon. Aalborg, Denmark

Schmidt J, De Rosa M (2018) Comparative LCA of RSPO certified and non-certified palm oil - revised final draft after 1st round critical review dated 19th March 2019. Aalborg, Denmark

Schmidt J, Saxcé DM (2016) Arla Foods Environmental Profit and Loss Accounting 2014. Copenhagen

Schmidt JH, Weidema BP, Brandão M (2015) A framework for modelling indirect land use changes in Life Cycle Assessment. J Clean Prod 99:230-238. https://doi.org/10.1016/j.jclepro.2015.03.013

Tilman D, Fargione J, Wolff B, et al (2001) Forecasting agriculturally driven global environmental change. Science (80- ) 292:281 LP 284. https://doi.org/10.1126/science. 1057544

Trabelsi D, Mhamdi R (2013) Microbial inoculants and their impact on soil microbial communities: a review. Biomed Res Int 2013:1-11. https://doi.org/10.1155/2013/863240

USDA (2019) Economic Research Service. https://data.ers.usda.gov/ reports.aspx?ID=17883. Accessed 20 Sep 2004

van Noordwijk M, Brussaard L (2014) Minimizing the ecological footprint of food: closing yield and efficiency gaps simultaneously? Curr Opin Environ Sustain 8:62-70. https://doi.org/10.1016/j.cosust. 2014.08.008

Weidema B (2003) Market information in life cycle assessment

Weidema B, Hauschild M, Jolliet O (2008) Preparing characterisation methods for endpoint impact assessment. In: Weidema BP, Wesnae M, Hermansen J, et al. (eds) Environmental improvement potentials of meat and dairy products. Institute for Prospective Technological Studies, Seville

Weidema BP (2009) Using the budget constraint to monetarise impact assessment results. Ecol Econ. https://doi.org/10.1016/j.ecolecon. 2008.01.019

Weidema BP, Ekvall T, Heijungs R (2009) Guidelines for application of deepened and broadened LCA, Deliverable D18 of work package 5 of the CALCAS project

Wernet G, Bauer C, Steubing B et al (2016) The ecoinvent database version 3 (part I): overview and methodology. Int J Life Cycle Assess 21:1218-1230. https://doi.org/10.1007/s11367-016-1087-8

Yao G, Hertel TW, Taheripour F (2018) Economic drivers of telecoupling and terrestrial carbon fluxes in the global soybean complex. Glob Environ Chang 50:190-200. https://doi.org/10.1016/j.gloen vcha.2018.04.005

Publisher's Note Springer Nature remains neutral with regard to jurisdictional claims in published maps and institutional affiliations. 